\title{
Changes in Mountain Big Sagebrush Habitat Types Following Spray Release
}

RICHARD F. MILLER, ROGER R. FINDLEY, AND JEAN ALDERFER-FINDLEY

\section{Abstract}

Three habitats dominated by mountain big sagebrush were sprayed with 2,4-D butyl ester. Shrub cover in sprayed mountain big sagebrush communities was significantly less than unsprayed. Perennial grass production and density were twice as high across sprayed stands as compared with nonsprayed stands. Across the three habitat types bluebunch wheatgrass productivity was more responsive on the sprayed stands than Idaho fescue. Production and density of tailcup lupine, the most abundant forb across the three sites, was significantly less in sprayed communities, causing total forb production to be lower. Other forbs either showed little or no difference in production and density between the sprayed and nonsprayed communities.

Intensive management of our resources requires accurate biological information. The need for plant response data in chemical control programs on rangelands has intensified due to an increase in users of this resource. Land managers must be able to predict accurately the outcome of brush control programs. Researchers have reported numerous examples of increases in forage production and beef production following chemical control of sagebrush (Artemisia tridentata) (Hyder and Sneva 1956; Hedrick et al. 1966; Laycock and Phillips 1968; Sneva 1972; Schumaker and Hanson 1977; and Sturges 1977). Information is also available on changes in plant composition following brush control with 2,4-D (2,4-dichlorophenoxy acetic acid) (Hurd 1955; Blaisdell and Mueggler 1956; Findley 1974; Sturges 1977; and Tomkins and Grant 1977).

Although numerous publications have dealt with the effects of spraying big sagebrush, the specific subspecies being evaluated was rarely identified. Taxa of Artemisia tridentata not only vary morphologically and phenologically but also have distinct ecologic and hydrologic requirements (Beetle 1960; Beetle and Young 1965; Winward 1970; Winward and Tisdale 1977; West et al. 1978). Sturges (1977) reported parameters relating to available moisture which affect the distribution of sagebrush subspecies also influence soil moisture response following sagebrush control. Predictions of plant community response to chemical brush control may be more accurate in sagebrush communities if data were evaluated by sagebrush subspecies.

The purpose of this study was to document changes in forage production and plant species abundance following application of 2,4-D in three mountain big sagebrush (Artemisia tridentata subsp. vaseyana) habitat types. Habitat

Authors are assistant professor, Rangeland Resources Program, Oregon State University, Corvallis; instructor, Department of Agriculture, Treasure Valley Community College, Ontario, Oregon; and rangc conscrvationist, Burcau of Land Management, Vale, Oregon, respectively.

This report was submitted as Technical Paper No. 5054. Oregon Agricultural Experiment Station, Corvallis 97331.

Manuscript received January 8, 1979. types studied were: mountain big sagebrush/Idaho fescue (Artemisia tridentata subsp. vaseyana/Festuca idahoensis) and mountain big sagebrush/bluebunch wheatgrass (Artemisia tridentata subsp. vaseyana/Agropyron spicatum) (Winward 1970). The third community, mountain big sagebrush/Idaho fescue-bluebunch wheatgrass (Artemisia tridentata subsp. vaseyana/Festuca idahoensis-Agropyron spicatum), recognized as a distinctly different site by Sheehy (1975), will be called a habitat type in the following discussion although it has not been recognized at this level in the literature.

\section{Study Sites and Methods}

The study area is located in eastern Oregon approximately 14.5 $\mathrm{km}$ southwest of the town of Ironside. Topography is steep with elevations varying from 1,830 to $2,377 \mathrm{~m}$. Vegetation on the upper slopes is dominated by mountain big sagebrush, with Idaho fescue on the north-facing slopes and bluebunch wheatgrass on the southfacing slopes. Both grasses were commonly associated on the northwesterly slopes. Weather data recorded in the town of Ironside show annual precipitation averages $400 \mathrm{~mm}$ with the majority falling as snow in the winter. Precipitation recorded at the nearby U.S. Weather Station was $47 \%$ of average in 1977 and $132 \%$ of average in 1978. The mountain big sagebrush/Idaho fescue site was located on the top of a north-northwest exposure with a $13 \%$ slope. Soils were rocky averaging less than $45 \mathrm{~cm}$ in depth. The mountain big sagebrush/bluebunch wheatgrass stand was on a south-southeast exposure with a $38 \%$ slope. Soils averaged $90 \mathrm{~cm}$ in depth and were somewhat rocky. The mountain big sagebrush/Idaho fescue/bluebunch wheatgrass site had deep soils, with a $44 \%$ northwest slope. These stands are under private ownership and have not been grazed until seed set since 1974. Prior to 1974 previous owners grazed this area season-long under heavy stocking rates from the late 1950's until 1973.

In 1974 the area was sprayed with $2.2 \mathrm{~kg}$ a.e./ ha of 2,4-D butyl ester in water by helicopter during the last week of May. No flagmen were used resulting in alternate spray strip patterns. One plant community was selected for each of the three sprayed and nonsprayed habitat types. The six communities were selected on the basis of their homogeneity and the presence of adjacent sprayed and nonsprayed strips. In most cases treated or nontreated communities in each habitat type were not contiguous due to the alternating pattern of herbicide application. Sampling was done on adjacent alternating sprayed and nonsprayed communities occurring on the same slope characterized by similar aspect, steepness and soils in each habitat type. Fifteen transects $100 \mathrm{~m}$ long were located parallel to the slope contour in both sprayed and nonsprayed communities. Density data for forbs and grasses were recorded in 1977 for each spccics in rectangular $0.2 \mathrm{~m}^{2}$-plots. Plots were placed at $10-\mathrm{m}$ increments along the fifteen $100 \mathrm{~m}$ long transects totaling 150 plots in each community (Brown 1956; Strickler and Stearns 1962). A plant was counted inside the plot if the main stem or stems were rooted inside the plot if the main stem 


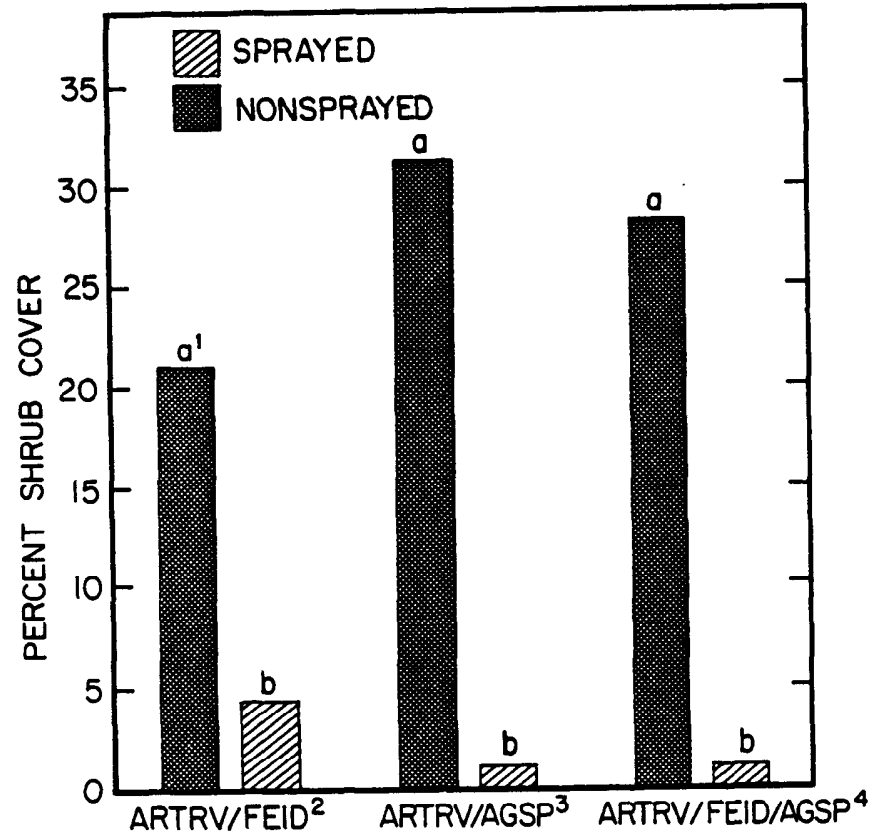

Fig. 1. Percent shrub canopy cover in sprayed and nonsprayed plant communities in each of the three habitat types.

'Bars designated by different letters are significantly different at the $95 \%$ confidence level within habitat types.

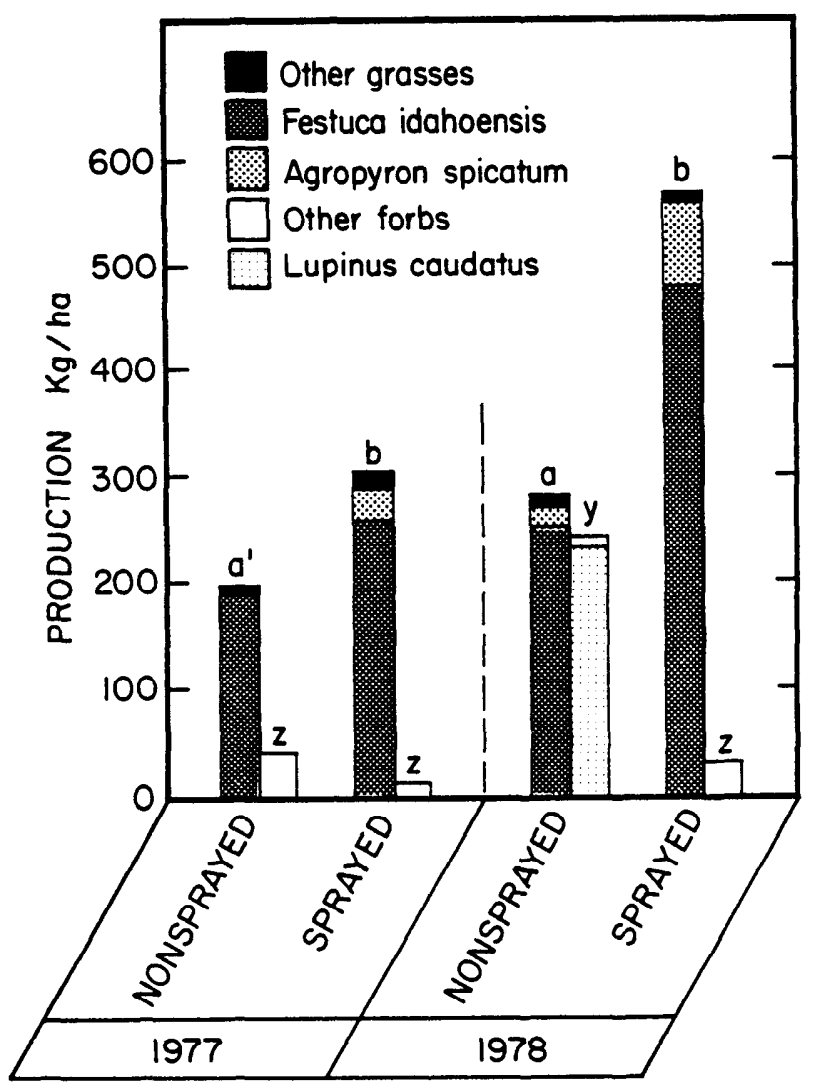

Fig. 2. Grass and forb production on nonsprayed and sprayed Artemisia tridentata subsp. vaseyana/Festuca idahoensis habitat type in 1977 and 1978.

'Bars designated by different letters are significantly different at the $95 \%$ confidence level between grasses or between forbs within years. or stems were rooted inside the perimeter. Nine randomly selected 100-m line intercepts, located on the slope contour were used to measure shrub cover in both sprayed and nonsprayed habitat types in 1977 (Canfield 1941). The area of ground covered by the vertical projection of the canopy for each shrub species were recorded. Ninety $0.45-\mathrm{m}^{2}$ circular plots in each sprayed and nonsprayed community were sampled for production in 1977 and 1978 by the ocular weight estimate method (Pechanec and Pickford 1937). Estimates were corrected by double sampling (Wilm et al. 1944). Plots were located at $10-\mathrm{m}$ increments along nine randomly distributed 100-m tapes placed parallel to the slope contour. Plant material from each species was collected, oven dried at $60^{\circ} \mathrm{C}$ for $48 \mathrm{hr}$, and then weighed to the nearest gram on a top loading Mettler balance. Paired treated and untreated communities were tested with the Student's $t$ test by species for density, cover, and production. All statistical results were tested at $95 \%$ confidence level.

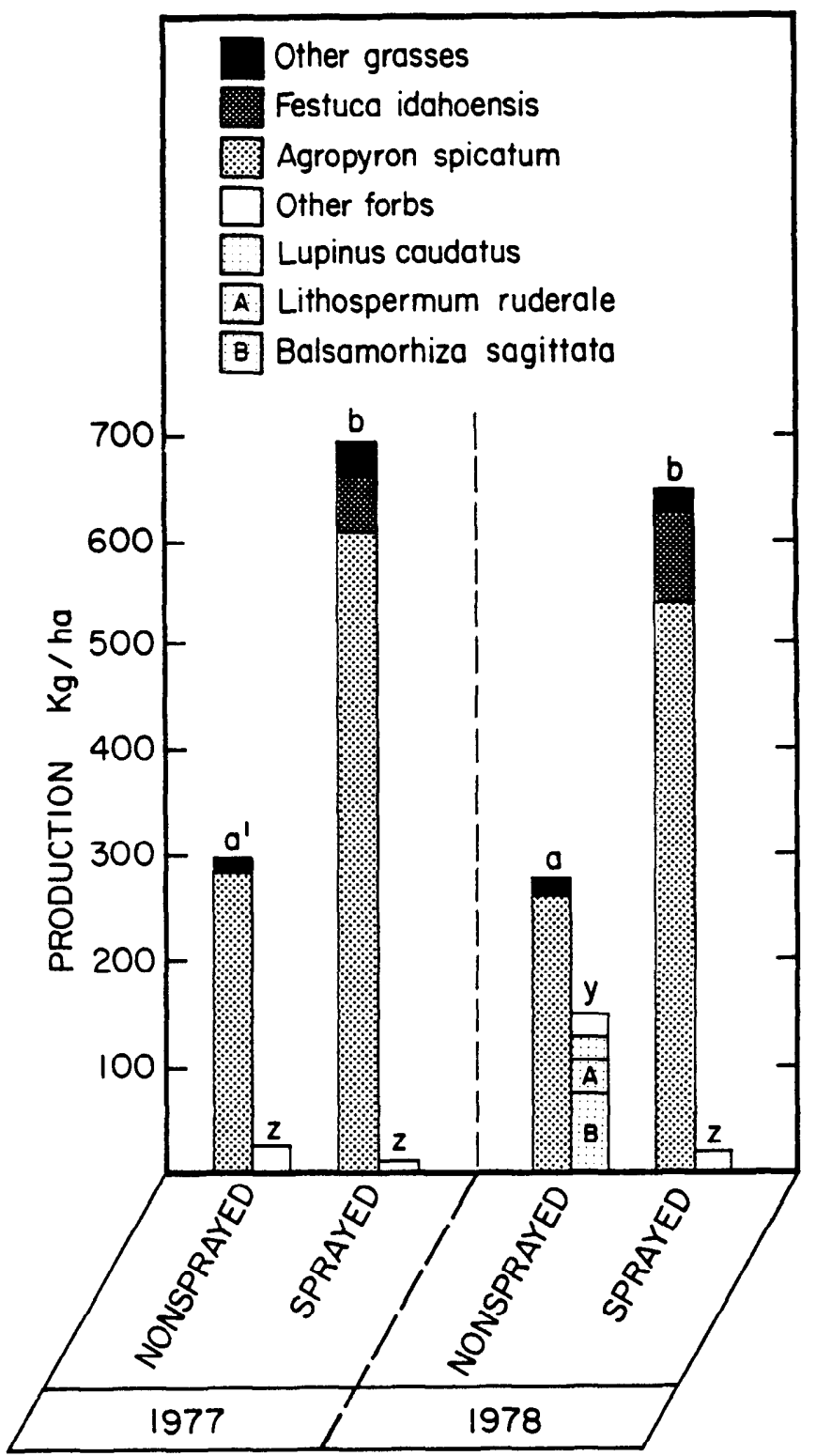

Fig. 3. Grass and forb production on nonsprayed and sprayed Artemisia tridentata subsp. vaseyana/Agropyron spicatum habitat type in 1977 and 1978.

'Bars designated by different letters are significantly different at the $95 \%$ confidence level between grasses or between forbs within years, 


\section{Results and Discussion}

\section{Shrub Cover}

Three years following application of 2,4-D on three mountain big sagebrush habitat types, mountain big sagebrush canopy cover was significantly less on the sprayed stands (Fig. 1). Comparative differences of shrub canopy cover between sprayed and nonsprayed communities ranged from 81,95 , and $97 \%$ less cover on the treated mountain big sagebrush/Idaho fescue, mountain big sagebrush/Idaho fescue/bluebunch wheatgrass, and mountain big sagebrush/bluebunch wheatgrass habitat types, respectively.

\section{Grass Production and Composition}

Significant differences in grass production between treated and nontreated communities were measured on all three habitat types in the third and fourth years following sagebrush control (Figures 2, 3, and 4). Perennial grasses on all three treated sites averaged $307 \mathrm{~kg} / \mathrm{ha}$ more production than nontreated sites, excluding 1977 production on the mountain big sagebrush/Idaho fescue site. This was the only site where perennial grass production was significantly affected by the low levels of precipitation during 1977.

Bluebunch wheatgrass appeared to be more consistently responsive to increase in a spray release program than Idaho fescue. Over the 2 years bluebunch wheatgrass production averaged $308 \mathrm{~kg}$ / ha higher on the sprayed community as compared to the nonsprayed community in the mountain big sagebrush/bluebunch wheatgrass habitat type. However, Idaho fescue averaged only $146 \mathrm{~kg} / \mathrm{ha}$ and $33 \mathrm{~kg} / \mathrm{ha}$ more production on sprayed than on nonsprayed communities in the mountain big sagebrush/Idaho fescue and mountain big sagebrush/Idaho fescue-bluebunch wheatgrass habitat types, respectively. In the mountain big sagebrush/Idaho fescue/bluebunch wheatgrass habitat type where Idaho fescue did not produce significantly more biomass on the sprayed community, bluebunch wheatgrass produced $140 \mathrm{~kg} /$ ha (a 6-fold increase) more biomass on the sprayed community as compared to the nonsprayed community. Schumaker and Hanson (1977) reported similar results on a mountain big sagebrush/Idaho fescue community following chemical control where Idaho fescue increased from 69 to 88 $\mathrm{kg}$ / ha and bluebunch wheatgrass 35 to $120 \mathrm{~kg} / \mathrm{ha}$ following treatment.

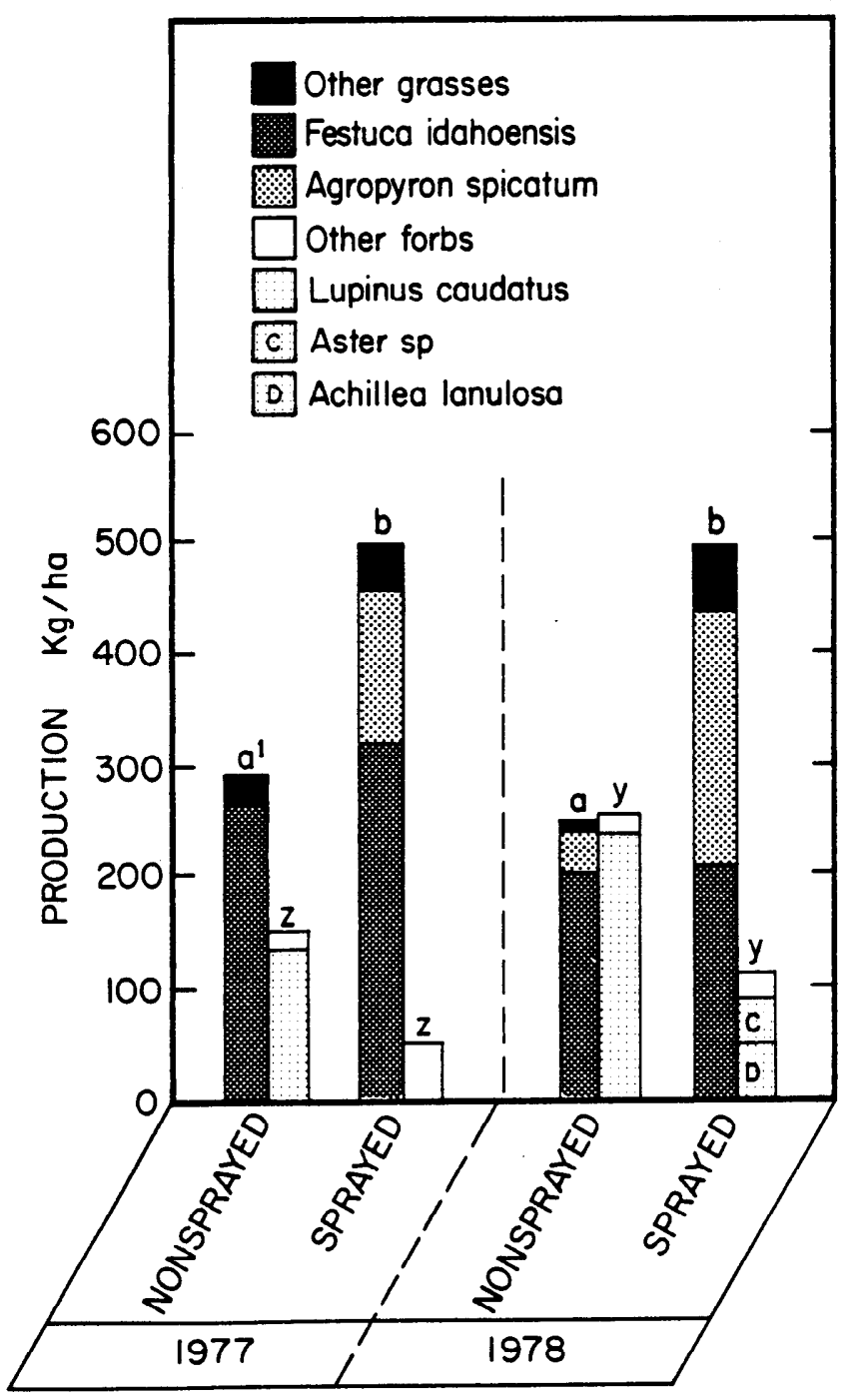

Fig. 4. Grass and forb production on nonsprayed and sprayed Artemisia tridentata subsp. vaseyana/Festuca idahoensis-Agropyron spicatum habitat type in 1977 and 1978.

'Bars designated by different letters are signicantly different at the $95 \%$ confidence level between grasses or between forbs within years.

Table 1. Density (plants $/ \mathrm{m}^{2}$ ) in sprayed and nonsprayed communities in 1977 for in the three habitat types.

\begin{tabular}{|c|c|c|c|c|c|c|}
\hline \multirow[b]{2}{*}{ Species } & \multicolumn{2}{|c|}{ ARTRV/FEIDI } & \multicolumn{2}{|c|}{ ARTRV/AGSP2 } & \multicolumn{2}{|c|}{ ARTRV/FEID/AGSP } \\
\hline & Non-sprayed & Sprayed & Non-sprayed & Sprayed & Non-sprayed & Sprayed \\
\hline Festuca idahoensis & 17 & $27^{* 4}$ & $t$ & $1^{*}$ & 18 & 21 \\
\hline Agropyron spicatum & 2 & $11^{*}$ & 4 & $8^{*}$ & 1 & $5^{*}$ \\
\hline Poa sandbergii & 5 & $10^{*}$ & 0 & 0 & 3 & $6^{*}$ \\
\hline Bromus tectorum & 0 & 0 & 1 & 4 & 0 & 2 \\
\hline Other grasses & 0 & 0 & $t$ & $\mathrm{t}$ & 1 & 2 \\
\hline Total grasses & 24 & $48^{*}$ & 6 & $13^{*}$ & 23 & $36^{*}$ \\
\hline Lupinus caudatus & 5 & $\mathrm{t}^{*}$ & 0 & $\mathrm{t}$ & 9 & $t^{*}$ \\
\hline Arenaria nuttallii & 3 & 7 & $t$ & 1 & 0 & 0 \\
\hline Erigeron pumulis & 4 & 2 & 0 & 0 & 7 & 6 \\
\hline Achillea lanulosa & 0 & 0 & 0 & 0 & 1 & $13^{*}$ \\
\hline Balsamorhiza sagittata & 0 & 0 & $\mathrm{t}$ & 0 & 0 & 0 \\
\hline Other forbs & $\mathrm{t}$ & $\mathrm{t}$ & $t$ & $t$ & 3 & 3 \\
\hline Total forbs & 16 & 12 & $\mathrm{t}$ & 2 & 20 & 22 \\
\hline
\end{tabular}

'Artemisia tridentata subsp. vaseyana/Festuca idahoensis

${ }^{2}$ Artemisia tridentata subsp. vaseyana/Agropyron spicatum

${ }^{3}$ Artemisia tridentata subsp. vaseyana/Festuca idahoensis-Agropyron spicatum

${ }^{4 *}$ Significantly different at the 0.05 probability level.

Other forbs 
On these sites residual levels of perennial grasses in the nonsprayed communities appeared to be adequate for spray-release. Hyder and Sneva (1956) reported that 168 $\mathrm{kg} /$ ha of bluebunch on Wyoming big sagebrush range was satisfactory for spray release. On all three habitat types the source of increased forage production was partially due to an increase in newly established plants (Table 1). Hyder and Sneva (1956) reported that increase in bunchgrass production following spraying Wyoming big sagebrush was partially due to newly established plants and an increase in basal area, but primarily caused by an increase in plant height. Blaisdell (1949) concluded increased yields following sagebrush control were due to the release of suppressed established plants rather than establishment of new plants.

\section{Forb Production and Composition}

Forb production was significantly lower in sprayed communities in all three habitat types (Figs 2,3, and 4). Forb species primarily responsible for differences in total production between sprayed and nonsprayed communities were tailcup lupine (Lupinus caudatus), arrowleaf balsamroot (Balsamorhiza sagittata), and wayside gromwell, (Lithospermum ruderale). Schumaker and Hanson (1970) reported a reduction in arrowleaf balsamroot following herbicide control of big sagebrush in Idaho. In the mountain big sagebrush/Idaho fescue/bluebunch wheatgrass habitat type, yarrow (Achillea lanulosa) was higher in both production and density (Table 1 ) in the sprayed community. Several other authors have found yarrow unaffected by 2,4-D (Hurd 1955; Laycock and Philips 1968). Aster foliaceus also significantly produced more on the sprayed plots in 1978 . Hurd (1955) reported this species to be only moderately affected by 2,4-D. Application of 2,4-D appeared to have little if any effect on many of the other forbs present; however, due to their low numbers these plants were inadequately sampled. Also, time of sampling occurred after peak production of most forbs.

\section{Literature Cited}

Beetle, A.A. 1960. A study of sagebrush the section tridentatae of Artemisia. Wyoming Agr. Exp. Sta. Bull. 368, 83 p.
Beetle, A.A. and A. Young. 1965. A third subspecies in the Artemisia tridentata complex. Rhodora 67: 405-406.

Blaisdell, J.P. 1949. Competition between sagebrush seedlings and reseeded grasses. Ecol. 30: 512-519.

Blaisdell, J.P., and W.F. Mueggler. 1956. Effect of 2,4-D on forbs and shrubs associated with big sagebrush. J. Range Manage. 9: 38-40.

Brown, D. 1954. Methods of surveying and measuring vegetation. Commonwealth Agr. Bureau. London, Canterbury. 223 p.

Canfield, R.H. 1941. Application of the line interception method in sampling vegetation. J. Forestry 39: 388-394.

Findley, R.R. 1974. Changes in plant communities following rangeland brush control. M.S. Thesis. Oregon State University. Corvallis. 98 p.

Hedrick, D.W., D.N. Hyder, F.A.Sneva, and C.E. Poulton. 1966. Ecological response of sagebrush-grass range in central Oregon to mechanical and chemical removal of Artemisia. Ecol. 47: 432-439.

Hurd, R.M. 1955. Effects of 2,4-D on some herbaceous range plants. J. Range Manage. 8: 126-128.

Hyder, D.N., and F.A. Sneva. 1956. Herbage response to sagebrush spraying. J. Range Manage. 9: 54-58.

Laycock, W.A., and T.A. Phillips. 1968. Long-term effects of 2,4-D on lanceleaf rabbitbrush and associated species. J. Range Manage. 21: 90-93.

Pechanec, J.F., and G.D. Pickford. 1937. A weight estimate method for determination of range pasture production. J. Amer. Soc. Agron. 29: 894-904.

Schumaker, G.A., and C.L. Hanson. 1977. Herbage response after mechanical and herbicide treatment of big sagebrush in southwest Idaho. U.S. Dep. Agr., Agr. Res. Ser. ARS W-46. 15 p.

Sheehy, D. 1975. Relative palatability of seven Artemisia taxa to mule deer and sheep. M.S. Thesis. Oregon State Univ. Corvallis. 147 p.

Sneva, F.A. 1972. Grazing return following sagebrush control in eastern Oregon. J. Range Manage. 25: 174-178.

Strickler, G.S., and F.W. Stearns. 1962. The determination of plant density. U.S. Dep. Agr. Misc. Pub. 940.40 p.

Sturges, D.L. 1977. Soil moisture response to spraying big sagebrush: a seven-year study and literature interpretation. U.S. Dep. Agr. Rocky Mountain Forest and Range Exp. Sta. Res. Paper RM-188.

Tomkins, D.J., and W.F. Grant. 1977. Effects of herbicides on species diversity of two plant communities. Ecol. 58: 398-406.

West, N.E., R.J. Rausch, K.H. Rea, and P.T. Tueller. 1978. Taxonomic determination, distribution, and ecological indicator values of sagebrush within pinyon-juniper woodlands of the Great Basin. J. Range Manage. 31: 87-92.

Wilm, H.G., D.F. Costello, and G.E. Klipple. 1944. Estimating forage yield by double sampling method. J. Amer. Soc. Agron. 36: 194-203.

Winward, A.H. 1970. Taxonomic and ecological relationships of big sagebrush complex in Idaho. PhD diss. Univ. of Idaho, Moscow. $80 \mathrm{p}$.

Winward, A.H., and E.W. Tisdale. 1977. Taxonomy of the Artemisia tridentata complex in Idaho. Univ. of Idaho, Forest Wildl. and Range Exp. Sta. Bull. 19.

CHANGE OF ADDRESS notices should be sent to the Managing Editor, 2760 West Fifth Ave., Denver, Colo. 80204 , no later than the first day of the month of issue. Copies lost due to change of address cannot be replaced unless adequate notice is given. To assure uninterrupted service, provide your local postmaster with a Change of Address Order (POD Form 3575) indicating thereon to guarantee forwarding postage for second-class mail. 